\title{
Exploring Fear of Public Speaking Through Social Cognitive Theory
}

Nursuhaila Ibrahim, Nur Alyani Khairol Anuar, Muhammad Irfan Mokhtar, Nursyuhada Zakaria, Nurul Hijah Jasman, Nurul Nadiah Rasdi

To Link this Article: http://dx.doi.org/10.6007/IJARBSS/v12-i1/11320～DOI:10.6007/IJARBSS/v12-i1/11320

Received: 09 November 2021, Revised: 15 December 2021, Accepted: 28 December 2021

Published Online: 10 January 2022

In-Text Citation: (Ibrahim et al., 2021)

To Cite this Article: Ibrahim, N., Anuar, N. A. K., Mokhtar, M. I., Zakaria, N., Jasman, N. H., \& Rasdi, N. N. (2021). Exploring Fear of Public Speaking Through Social Cognitive Theory. International Journal of Academic Research in Business and Social Sciences, 12(1), 135-154.

Copyright: (c) 2022 The Author(s)

Published by Human Resource Management Academic Research Society (www.hrmars.com)

This article is published under the Creative Commons Attribution (CC BY 4.0) license. Anyone may reproduce, distribute, translate and create derivative works of this article (for both commercial and non0-commercial purposes), subject to full attribution to the original publication and authors. The full terms of this license may be seen

at: http://creativecommons.org/licences/by/4.0/legalcode

Vol. 12, No. 1, 2022, Pg. 135 - 154

Full Terms \& Conditions of access and use can be found at http://hrmars.com/index.php/pages/detail/publication-ethics 


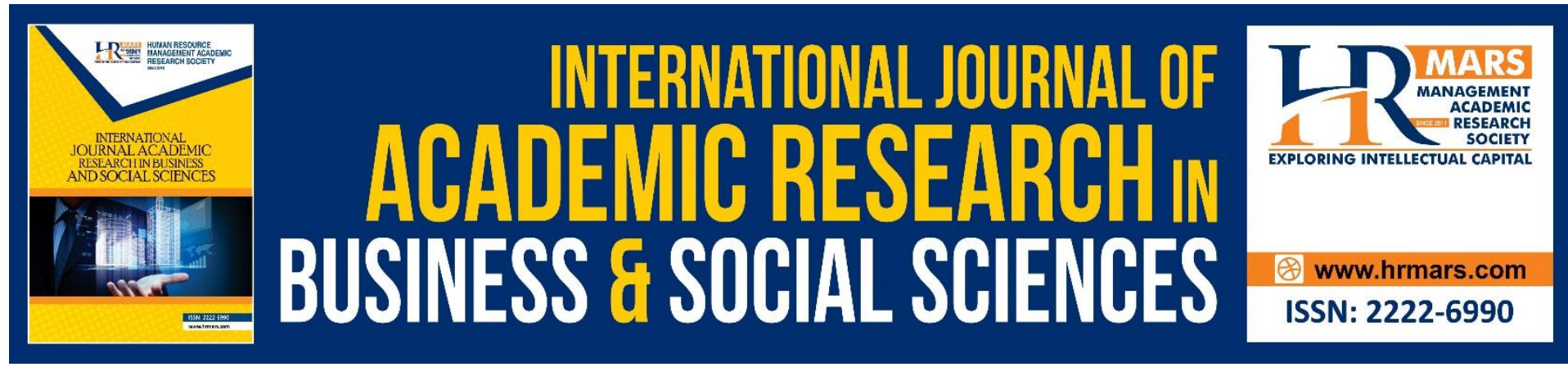

\title{
Exploring Fear of Public Speaking Through Social Cognitive Theory
}

\author{
Nursuhaila Ibrahim, Nur Alyani Khairol Anuar, Muhammad Irfan \\ Mokhtar, Nursyuhada Zakaria, Nurul Hijah Jasman, Nurul \\ Nadiah Rasdi \\ Academy of Language Studies, Universiti Teknologi MARA Cawangan Johor, Kampus Pasir \\ Gudang
}

Email: nursu957@uitm.edu.my, nural7146@uitm.edu.my,muham7133@uitm.edu.my, syuhadazakaria@uitm.edu.my,nurulhijah@uitm.edu.my,nurulnadiahrasdi@uitm.edu.my

\begin{abstract}
Public speaking as a form of communication skill has pervaded today's learning environment. It is in contrast to the previous method of delivery in which oral communication is obscure. The vicissitudes occur because students need to be competent in the field of academics. This skill is vital for students, but hitherto much difficult because of their anxiety. Additionally, students think that the act of giving a speech needs strong volition and confidence. Therefore, it is crucial for them to tackle the fear before they endure the real journey in professional working life. Hence, this study aims to analyse the causes of fear in public speaking among students and how Social Cognitive Theory influences this anxiety. This study employed a quantitative survey comprising four sections in order to get a more in-depth data analysis. A total of 171 undergraduate students from Universiti Teknologi MARA served as the respondents of this study. The findings reveal that the students are influenced by several internal and external factors that cause fear in public speaking. In response to the influence of Cognitive and Behavior factors, the majority of those surveyed indicated that the size of the audience and nervousness lead to students' anxiety. These findings add to a growing body of literature on the anxiety of public speaking as well as aid as a reference for students and teachers, especially in English classrooms. Future studies on the current topic are therefore recommended in order to corroborate the findings.
\end{abstract}

Keywords: Fear, Students, Communication, Public Speaking, Social Cognitive Theory

\section{Introduction}

Background of Study

Language serves as mean of communication between people. Speaking is one of the four language skills: reading, writing, listening, and speaking. According to Rivers (1981), speaking is used more frequently in comparison to reading and writing in communication. Most speaking takes place face-to-face and some even require a larger audience. Public speaking is defined by (Wrench et al., 2012) as a process of creating and conveying messages to the audience. Speaking for a larger audience or public speaking may cause anxiety and concern 
for some L2 learners. According to Bartholomay \& Houlihan (2016), fear of public speaking or public speaking anxiety affect one in every five persons. Learners who suffer from the fear of public speaking may find it challenging to convey their opinions, ideas, or knowledge. van Ginkel et al (2015) argue that competence in public speaking is one of the keys defining highly educated graduates. Fear of public speaking will cause communication breakdowns between the speaker and the listeners. The use of communication strategy will help learners to survive the communication breakdowns. Communication strategies contribute to the success of effective communication (Kencanawati, 2014). They are used to negotiate meaning when L2 learner and a speaker of the target language do not share both linguistic structures and sociolinguistic norms (O'Malley \& Chamot, 1990). It is then important for L2 learners to learn and explore more on communication strategies they can employ to perform better when speaking in public.

\section{Statement of Problem}

Communicating effectively is a crucial part of teaching and learning process. Learners need to be able to communicate effectively in order to achieve desired outcomes. One of the communication tasks is public speaking. Public speaking is considered as part of important communication skills for learners. Learners as young as primary school students have been fostered with public speaking skills (Herbein et al., 2018). Good public speaking skills will benefit learners in their academic, career and everyday life (Chollet et al., 2015). Public speaking competence is directly related with communication strategies employed by learners. According to Mitchell and Myles (1998), less competent learners utilise communication strategies to prevent impending communicative breakdowns and maintain interaction during oral exchanges. In a study by Bataineh et al (2017), they studied the influence of communication strategies teaching on Jordanian EFL sixth-grade students' speaking performance and strategy implementation. Their finding yields that the employment of communication strategies in language instruction enhances oral performance while also increasing strategy use. In another study by Tsang (2020), reveals that there is a significant link between learners' self-perceived oral presentation skill and their public speaking fear. Self-efficacy is one of the key constructs of social cognitive theory by Bandura (1997). When one has better self-efficacy, one will have better belief in his or her ability to perform a task. Self-efficacy is one of the key factors in learners' ability to perform well in public speaking. The role of self-efficacy in improving one's achievement with regard to the use learning strategies as well as goal setting has been documented in many bodies of research (Wang \& Pape, 2005; Tilfarlioğlu \& Ciftci, 2011; Anuar et al., 2018; Rose et al., 2018). One of the reasons for fear of public speaking is low self-esteem and confidence to talk in front of many people (Dansieh et al., 2021).

Hence, this study is done to investigate how social cognitive theory influences the fear of public speaking.

Research Questions

This study is done to answer the following questions;

1.2.1 How do situational factors influence the fear of public speaking?

1.2.2 How do cognitive factors influence the fear of public speaking?

1.2.3 How do behaviour factors influence the fear of public speaking? 


\section{Literature Review}

Introduction

This section discusses social cognitive theory, fear of public speaking, communication strategies, past studies; as well as, the conceptual framework of the study.

\section{Social Cognitive Theory}

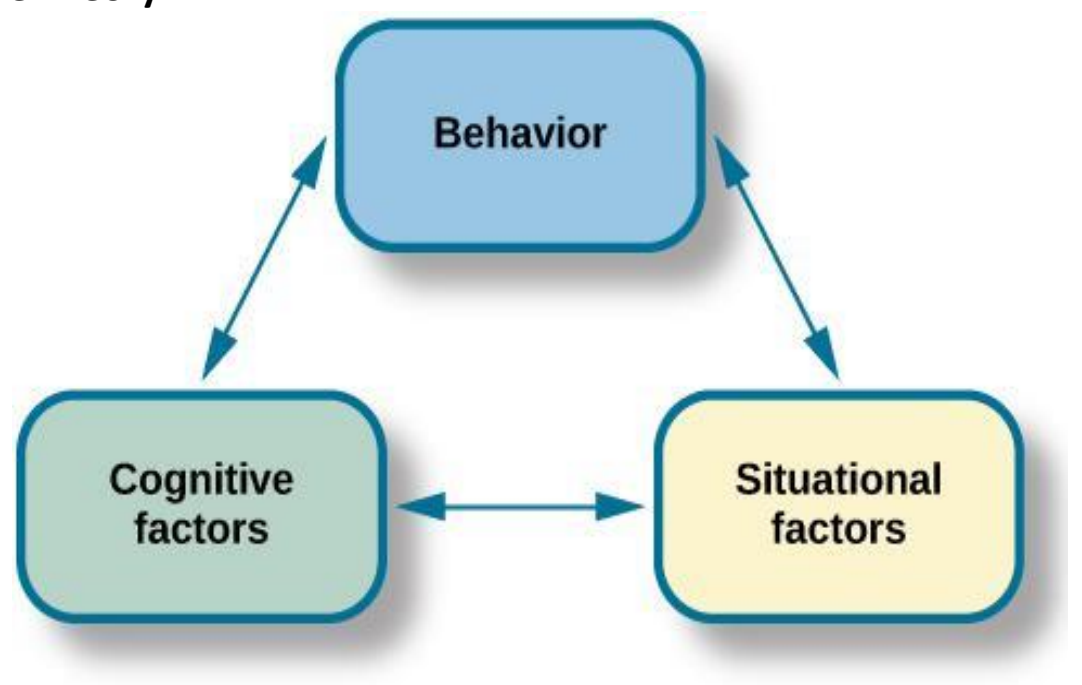

Figure 1 -SCT (Source: Bandura, 1986)

The social cognitive theory (figure 1) explains how both the environment and cognitive factors interact to influence learner's behavior. This theory was introduced by Bandura (1986). He said that learning is a dynamic interaction between people (cognitive factors), their environment (situational factors ). These factors influence the behaviour of the people involved.

\section{Fear of Public Speaking}

Fear of public speaking is undoubtedly common among language learners. Dwyer and Davidson (2012), reported that public speaking is on the top list of common fear among US college students. There are various terms used in describing the fear of public speaking such as communication apprehension McCroskey (1977), public speaking anxiety (Bodie, 2010) and glossophobia (Hancock et al., 2010). All of these varying terms pinpoint to situations where learners feel unease, worry and fear of speaking in public. According to Aida (1994), public speaking anxiety can be caused by several factors such as: fear of low evaluation by the teachers, fear or negative feedback by the listeners, and fear of past failures. Toubot, Seng and Abdullah (2017), highlighted six other factors including genetics, reinforcement, insufficient skill development, a lack of suitable role models, embarrassment, and other external conditions. Wang et al (2020) highlight the two types of public speaking anxiety; trait anxiety and state anxiety. Those who have a high level of public speaking anxiety are more likely to get physically stimulated. They will likely experience sweaty palms, racing heart beats or quivering speech. Public speaking anxiety is also classified as internal and external fears (LeFebvre et al., 2018). Internal fears refer to speakers' perception on the oral delivery and personal feelings, while external fears concern with the centre of attention from the audiences while delivering the speech (LeFebvre et al., 2018). 


\section{Theory for Communication Strategies}

There is a vast amount of literature on taxonomies of communication strategies for the past decades from various perspectives. Generally, the taxonomies differ in terms of definitions and how scholars categorize the strategies. The subcategories or specific strategies most likely remain the same. Tarone (1981), who proposed communication strategies from the interactionist point of view, suggested that communication strategies should meet the following criteria: 1) a situation where a speaker wishes to convey his intended meaning to a listener; 2) linguistic and sociolinguistic structures are not shared between the two interlocutors; and 3) the speaker then resorts to either avoiding talking about the topic or trying various ways to negotiate the meaning until it is mutually understood. She also identified five strategies namely paraphrase, borrowing, appeal for assistance, mime, and avoidance with subcategories illustrated for each strategy. In 2006, Nakatani designed the Oral Communication Strategy Inventory (OCSI) to shed light on more reliable methods to assess interactional aspects of communication. He classified the strategies into eight factors; namely social affective, fluency-oriented, negotiation for meaning while speaking, accuracyoriented, message reduction and alteration, non-verbal strategies while speaking, message abandonment, and attempt to think in English. OCSI has been adapted by various studies to examine learners' strategy use since its publication (Zhou \& Huang, 2018; Rastegar \& Gohari, 2016; Yaman \& Irgin, 2013, Nakatani, 2012). In addition, other comprehensive studies (Putri, 2013; Muhammad Sukirlan, 2014, Yusparizal et. al., 2018) used the classification of communication strategies that consists of avoidance or reduction strategies and achievement or compensatory strategies, with twelve subcategories overall, proposed by Dornyei (1995), as the base of their research. The avoidance strategies include message abandonment and topic avoidance; while achievement strategies include literal translation, borrowing/codeswitching, foreignizing, approximation, word coinage, circumlocution, use of all-purpose words, self-repair, appeals for assistance, and time-gaining strategies. Learners employ these strategies at varying degrees to help them achieve communicative goals whenever they face problems in their interactions.

\section{Past Studies on Fear of Public Speaking}

Grieve et. al (2021), conducted a qualitative study on fears of oral presentations and public speaking among forty-six university students of the West of England University, Bristol. The study aimed to learn more about the worries and methods employed by the participants who are afraid of public speaking as well as to determine if their fears had an effect on their college experience. Through thematic analysis, the fear of being evaluated, physical symptoms, ambiguity about the issue, negative influence on university experience, practice and preparation, and more practical support were all identified. The findings show that assignments on public speaking have a detrimental impact on learning and students' experience. Being judged and uncertain about the issues are the respondents' biggest anxieties. In spite of their dread of public speaking, the majority of the respondents in this study were aware of the need for practice and preparation. The findings also demonstrated a definite absence of and need for further comprehensive support for students who are afraid of public speaking.

A study by Dansieh (2021) also looked at the fear of public speaking among forty-six ESL students in Ghana. The study utilized both qualitative and quantitative research approaches, with a survey serving as the primary instrument among Dr. Hilla Limann Technical University final year secretarial undergraduates. The participants acknowledged the importance of 
public speaking, but admitted that glossophobia had prevented them from making a favorable impression on the audience at some point. It was reported that the participants' ability to speak English in public was hampered by several factors namely low self-confidence, a lack of consistent speaking experience, inadequate preparation and fear of making mistakes and being ridiculed at. The findings suggest that lecturers and teachers alike use an interactive approach along with proper communication strategies to foster positive attitudes and establish the desired atmosphere for improving students' confidence in order to help students overcome their fear of public speaking. Both studies show that educators play an important role in assisting students in overcoming their phobias of public speaking. Recognizing different learning styles and adopting a pleasant and inspiring classroom atmosphere are just a few of the steps that may be taken to guarantee that $L 2$ students have equal opportunities to succeed thereby aiding them in overcoming their public speaking anxieties (Mahmood, 2020; Singh, 2021).

Based on these studies, it is evident that fear of public speaking is a prevalent type of anxiety among learners from elementary schools to tertiary education. It might range from mild anxiety to paralysing fear and apprehension. Other glossophobia symptoms include stomach knots, sweaty palms, dry mouth, trembling legs, and throat tightness. According to the data gathered in the studies, students may prefer more practical support in smaller group workshops in a supportive environment, with a focus on authenticity, letting go of perfection, and substance over style (Mahmood, 2020; Danis, 2021; Grieve et.al., 2021). Nevertheless, in terms of the need for public speaking assistance, the issue of how students assessed existing support was not included and this deserves detailed investigation. Furthermore, most studies on glossophobia do not examine all three possible elements, namely situational, cognitive, and behavioural, at the same time and how these aspects affect the learners. As a result, the present study fits into existing literature.

\section{Past Studies on Communication Strategies}

Students employ many communication strategies to communicate and deliver their ideas effectively. A study by Panggabean and Wardhono (2017) looked at the types of communication strategies used by more proficient students and the type of communication strategies used by less proficient students. The participants were from three classes of the seventh semester, each of which consisted of 24 students. The research design of the study was qualitative, and the data were collected via observation of the participants when they had an oral presentation, fieldnotes, and documentation. The results indicated that students from the two levels of proficiency frequently used three types of communication strategies which were fillers or time-gaining strategy, repetition, and code switching. It is further revealed that the more proficient students seemed to be more efficient in using communication strategies. Consequently, they could explain their ideas more clearly and they seemed to be more confident in using English. In contrast, the less proficient students used a higher number of avoidance and appeal for help strategies. When facing problems in speaking, students will utilize communication strategies to cope with it. Zulkurnain and Kaur (2014) investigated the types of oral communication difficulties and the types of communication strategies used by the students to cope with speaking and listening problems during English oral communication activities. Questionnaires were distributed to a total of 100 Diploma of Hotel Management students at UiTM Permatang Pauh campus in Penang. Out of 100 students, 16 students participated in the focus group interviews and journal writing activity. In terms of communication difficulties faced, it is found that the students felt they 
did not know how to construct English sentences because of limited vocabulary, grammar, and structure. They also took too much time before producing English sentences because they wanted to produce accurate pronunciations of English. To overcome these communication difficulties, there were three highest coping strategies preferred by the students which are social affecting strategies, fluency-oriented strategies, and accuracy-oriented strategies. From past studies, it is found that there is a need to conduct a study on oral communication strategies focusing on accuracy-oriented strategies, message reduction, orientation and nonverbal strategies, social-affective strategies, fluency-oriented strategies, and negotiation for meaning strategies with subjects of different levels and fields especially in local context (Panggabean \& Wardhono, 2017; Zulkurnain \& Kaur, 2014; Tan, Mohd Nor, \& Jaradat, 2012).

\section{Conceptual Framework}

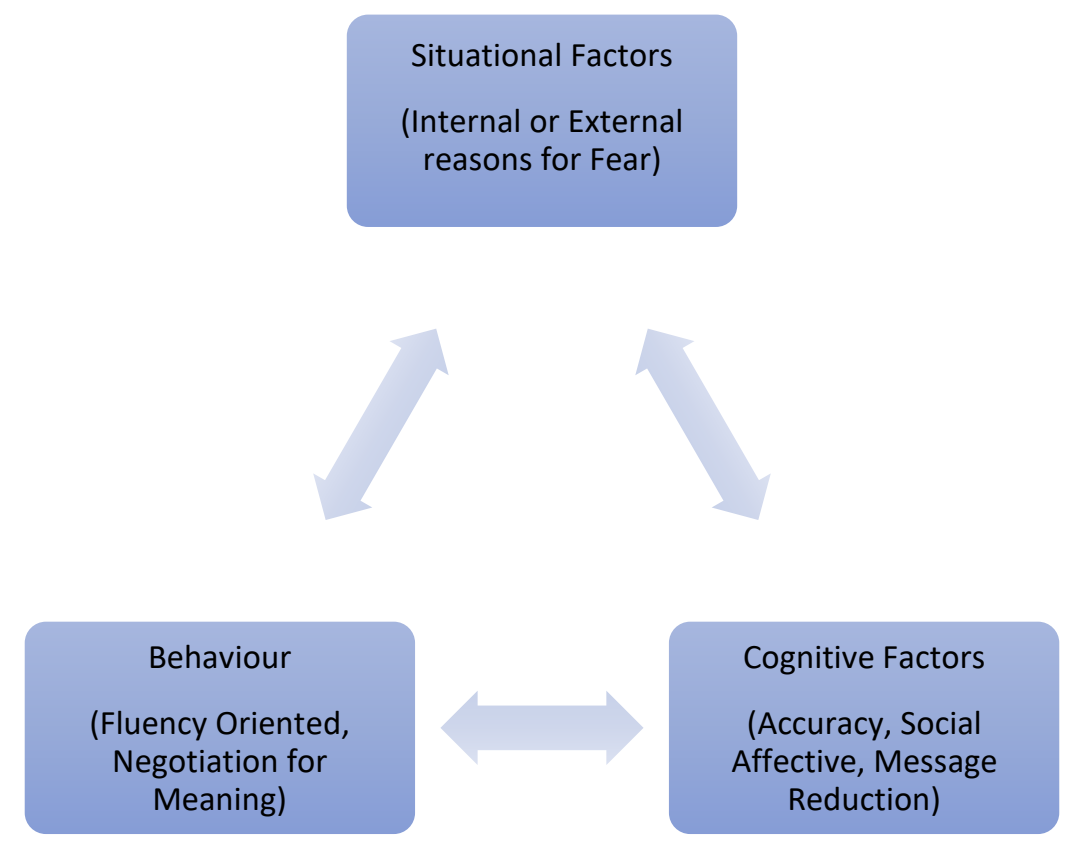

Figure 2-Conceptual Framework of the Study

This study (figure 2) is rooted from social cognitive theory (Bandura, 1986). Bandura's (1986) three factors of learning (a) situation, (b) cognitive and (c) behavioural are scaffolded onto Endler 's (19800 situational interaction and anxiety and Yaman and Kavasoglu's (2013) oral communication strategies. Situational factors are can cause internal and external reasons for fear. Next, cognitive factors such as accuracy, social affective and message reduction can cause fear of public speaking. Finally, learners may be more fluency oriented, and negotiate for meaning in their public speaking.

\section{Methodology}

This quantitative data is done to explore fear of public speaking through social cognitive theory. 171 participants responded to the instrument (a survey) The survey table 1 ) is adapted from items from (Endler, 1980; Yaman \& Kavasoglu, 2013). Section A has 4 items for demographic profiles. Section B has 14 items for situation factors, section has 16 items for cognitive factors and section $\mathrm{D}$ has 10 items for behavioural factors. 
Table 1-Distribution of Items in Instrument

\begin{tabular}{|l|l|l|l|}
\hline SECTION & FACTORS & & No of Items \\
\hline A & $\begin{array}{l}\text { Demographic } \\
\text { Profile }\end{array}$ & 4 \\
\hline B & SITUATIONAL & External & 7 \\
\hline & & Internal & 7 \\
\hline C & COGNITIVE & Social Affective & 6 \\
\hline & & Accuracy & 5 \\
\hline D & BEHAVIOUR & Message Reduction & 5 \\
\hline & & Negotiation of Meaning & 4 \\
\hline
\end{tabular}

An analysis of the instrument showed Cronbach alpha of .919 (table 2) thus revealing a high internal validity for the instrument chosen. Data is collected via Google Form and analysed using SPSS version 26. Data is presented in percentages for the demographic profile and mean scores to answer the research questions.

Table 2- Reliability Statistics

\section{Reliability Statistics}

\begin{tabular}{r|r}
$\begin{array}{c}\text { Cronbach's } \\
\text { Alpha }\end{array}$ & N of Items \\
\hline .919 & 40 \\
\hline
\end{tabular}

\section{Findings}

Introduction

This section discusses findings for the demographic profile and data to answer the research questions.

Findings for Demographic Profile

Gender

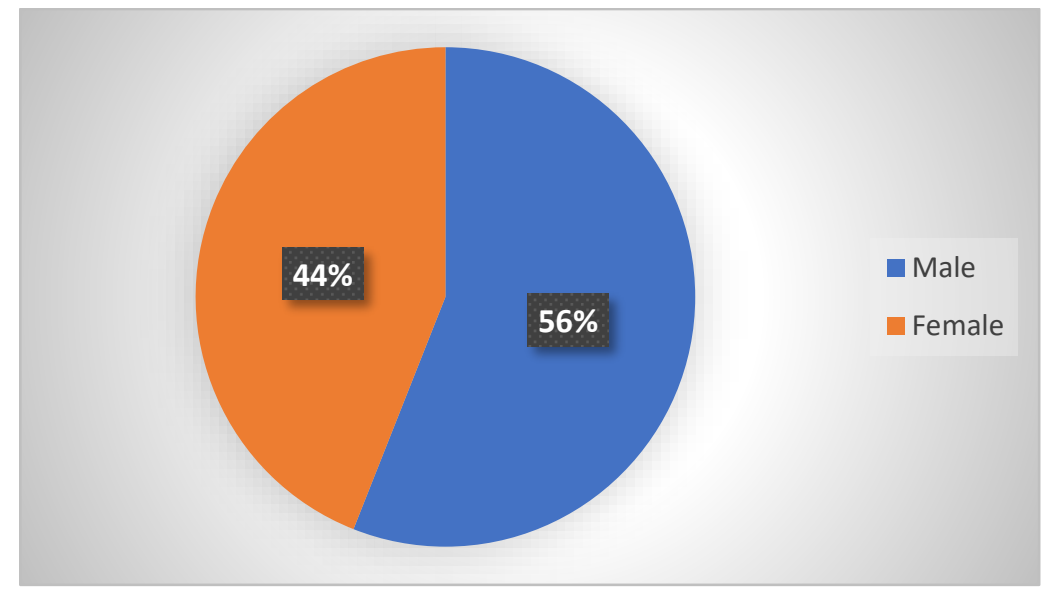

Figure 3- Percentage for Gender 
Figure 3 shows the distribution of gender consisting of $56 \%$ of males and $44 \%$ of females. Age Group

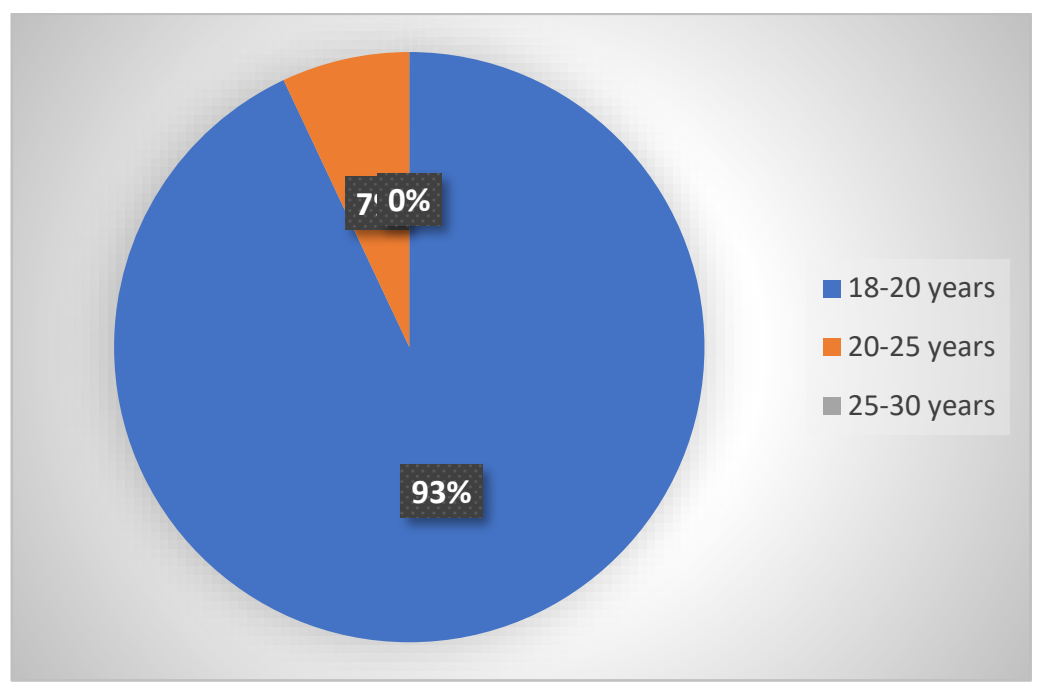

Figure 4- Percentage for Age Group

Distribution of age group in the study is illustrated in Figure 4. Majority of respondents in the study are $18-20$ years old at $93 \%$. The remaining $7 \%$ is the respondents from the age group of 20-25 years old.

Highest Academic Level

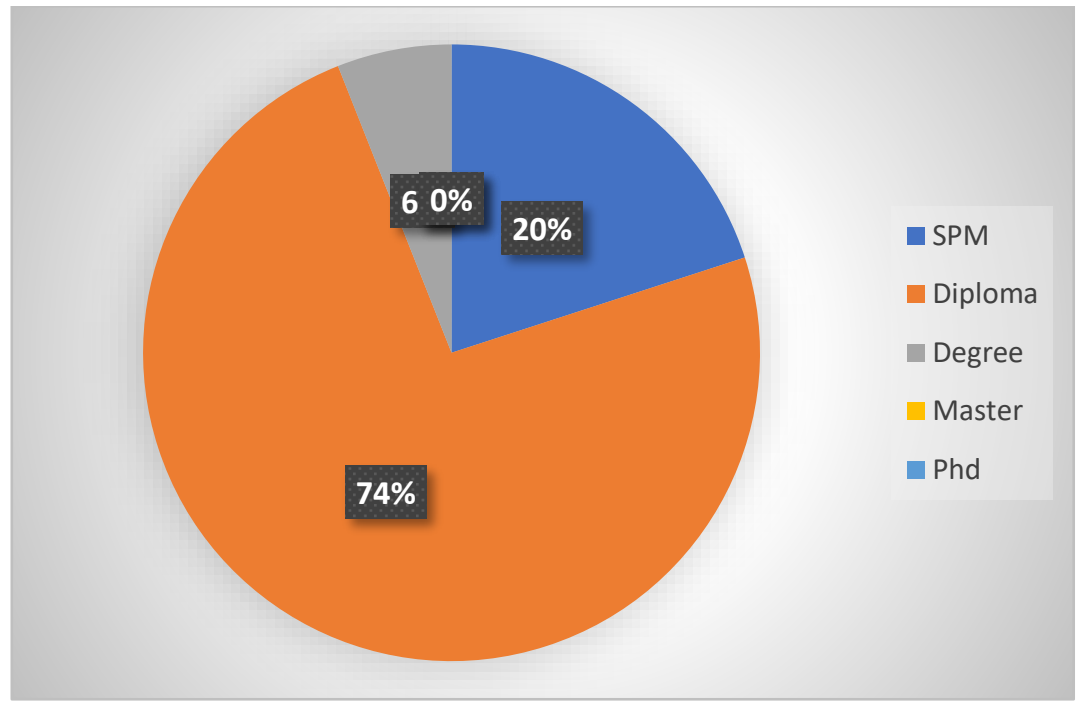

Figure 5-Percentage for Highest Academic level 
Figure 5 reveals the highest academic level of the respondents in the study. The highest academic level are Diploma (74\%), SPM (20\%), and Degree (5\%).

Semester Choices

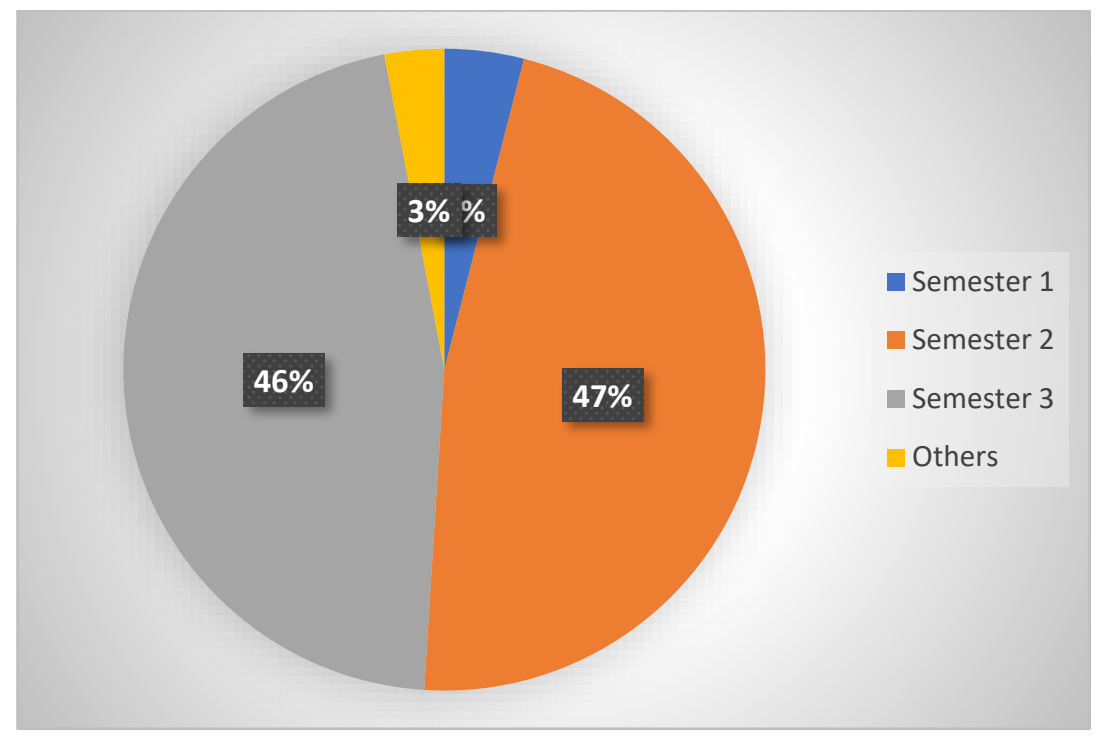

Figure 6- Percentage for Semester

Respondents in the study are from different semesters as shown in Figure 6 . They are from Semester 2 (47\%), Semester $3(46 \%)$, Semester 1 (4\%), and Others (3\%).

Findings for Situational Factors (through internal and external fear) This section presents data to answer research question 1: How do situational factors influence the fear of public speaking? The situational factors analysed are (i) internal and (ii) external reasons for fear.

\section{(i) External Factors}

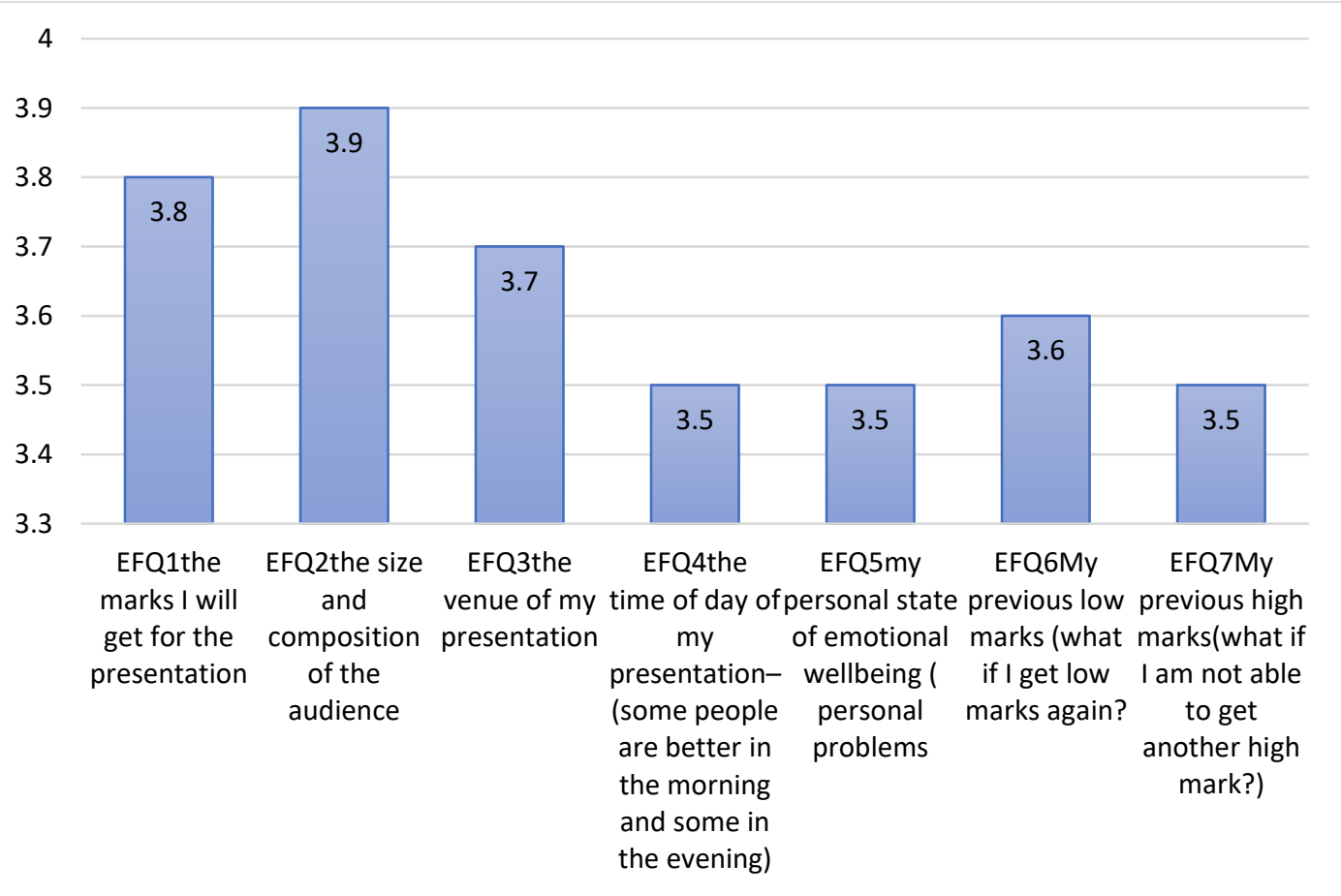

Figure 7- Mean for External factors 
Figure 7 shows the mean scores for seven external factors that contribute to public speaking anxiety. The most significant external factor that contributes to fear of public speaking was the size and composition of the audience with the highest mean score recorded $(M=3.9)$. Concern over the marks given by the examiner was the second most significant external factor with mean score recorded $(M=3.8)$. With the lowest mean score reported $(M=3.5)$, personal issues, time preferences, and worry about not being able to do better than the prior performance were the least important external factors for fear of public speaking.

\section{(ii) Internal Factors}

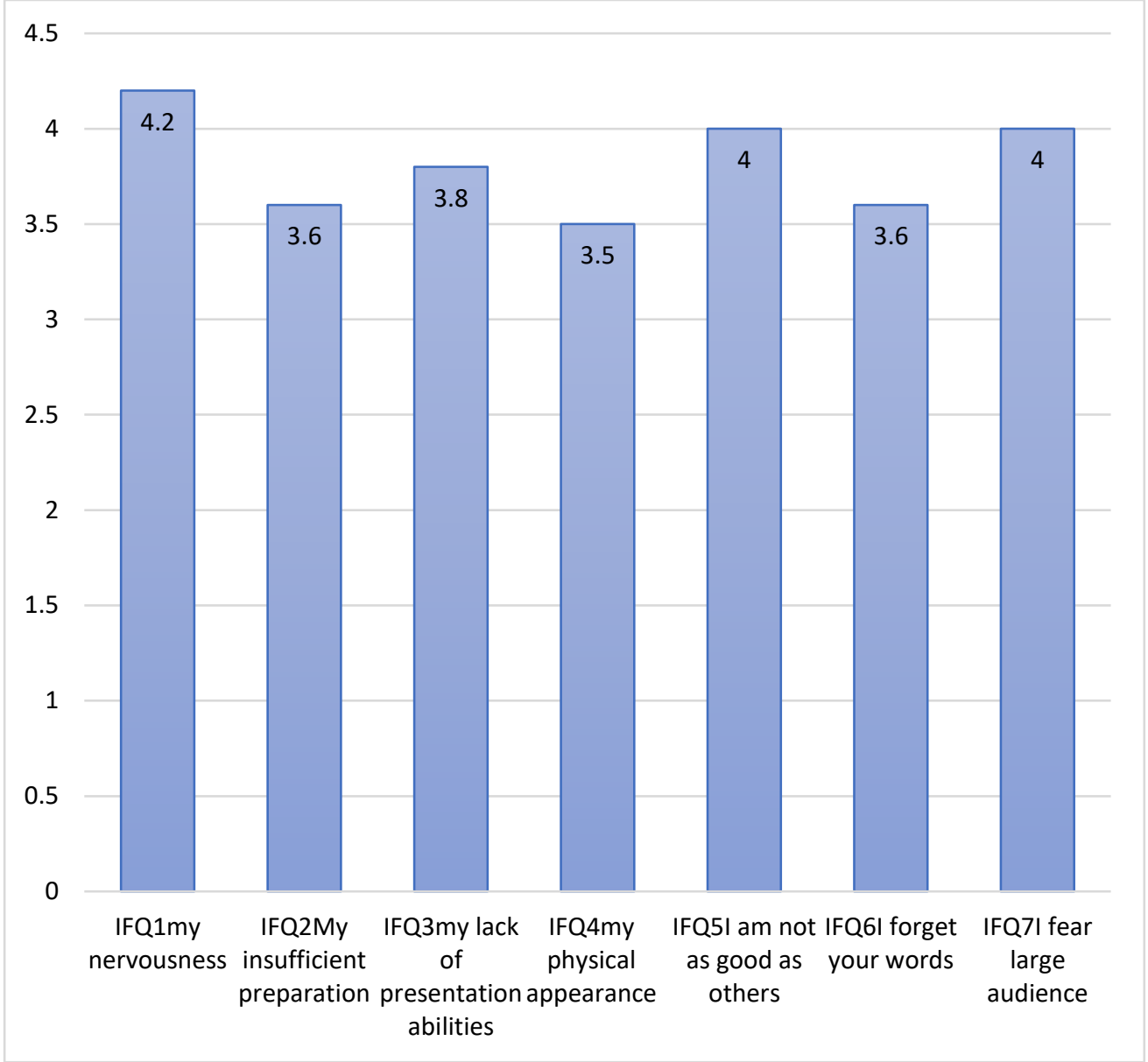

Figure 8- Mean for Internal Factors

Figure 8 illustrates the mean scores for seven internal factors that contribute to fear of public speaking. The most significant internal factor that contributes to fear of public speaking is the respondents' nervousness with the highest mean score recorded $(M=4.2)$. This is followed by their perception of not being good enough compared to others and the fear of large audiences $(M=4)$. The finding also revealed that physical appearance was the least important factor for fear in public speaking $(M=3.5)$. 
Findings for Cognitive Factors

This section presents data to answer research question 2: How do cognitive factors influence the fear of public speaking? Learners who fear public speaking would use (i) accuracy oriented strategies, (ii) social affective strategies and also (ii) message reduction strategies.

\section{(i) Accuracy Oriented Strategies}

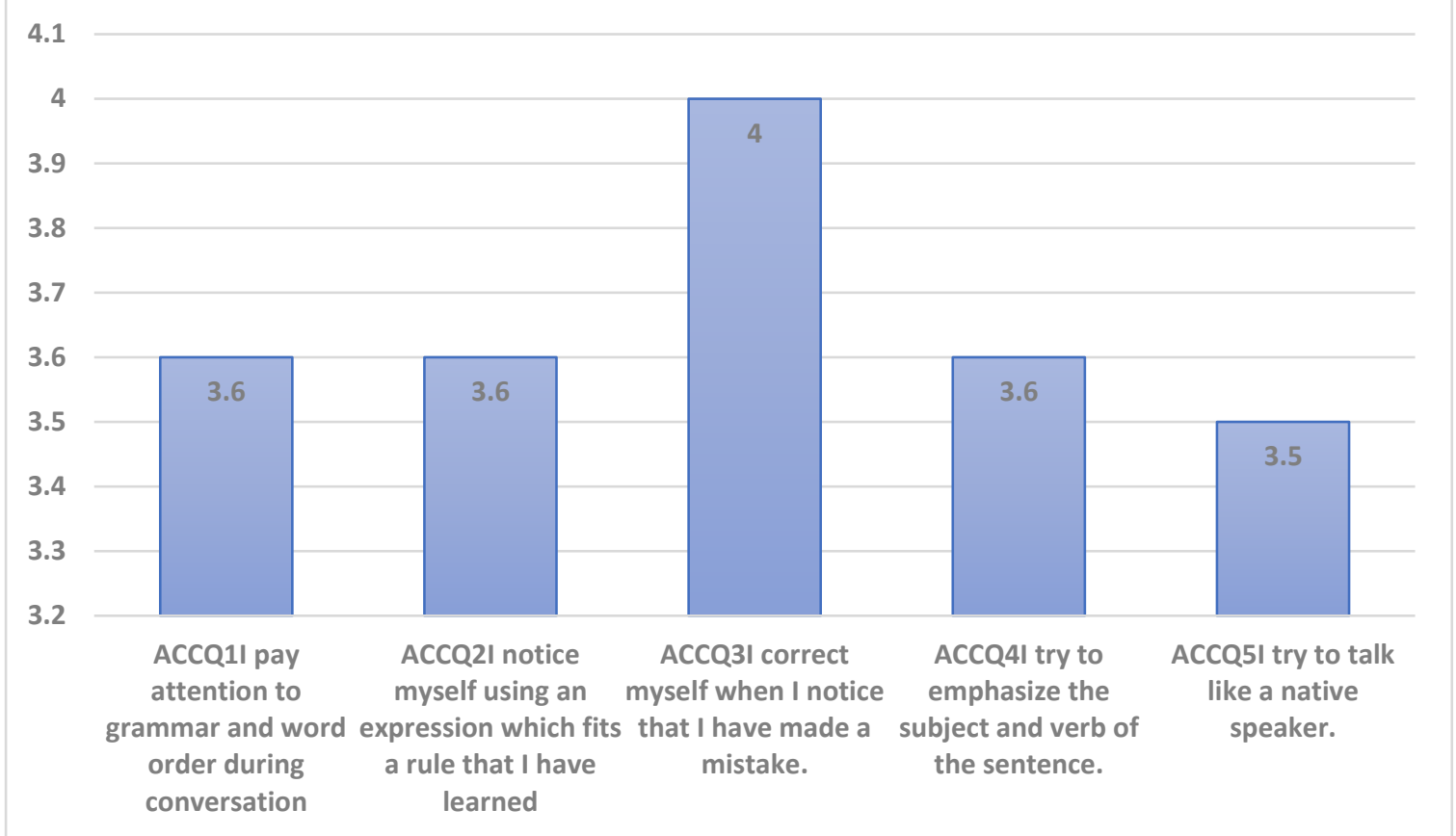

Figure 9- Mean for Accuracy Oriented Strategy

Figure 9 presents the mean scores for accuracy-oriented strategy. Respondents correct themselves when they have made a mistake has the highest mean score $(M=4)$. It is followed by three strategies that share the same mean score $(M=3.5)$ in which the respondents pay attention to grammar and word order during conversation, notice themselves using an expression which fits a rule that they have learned, and try to emphasize the subject and verb of the sentence. However, the strategy of respondents who do not try to talk like a native speaker is ranked as the lowest $(M=3.06)$. 


\section{(ii) Social-Affective Strategies}

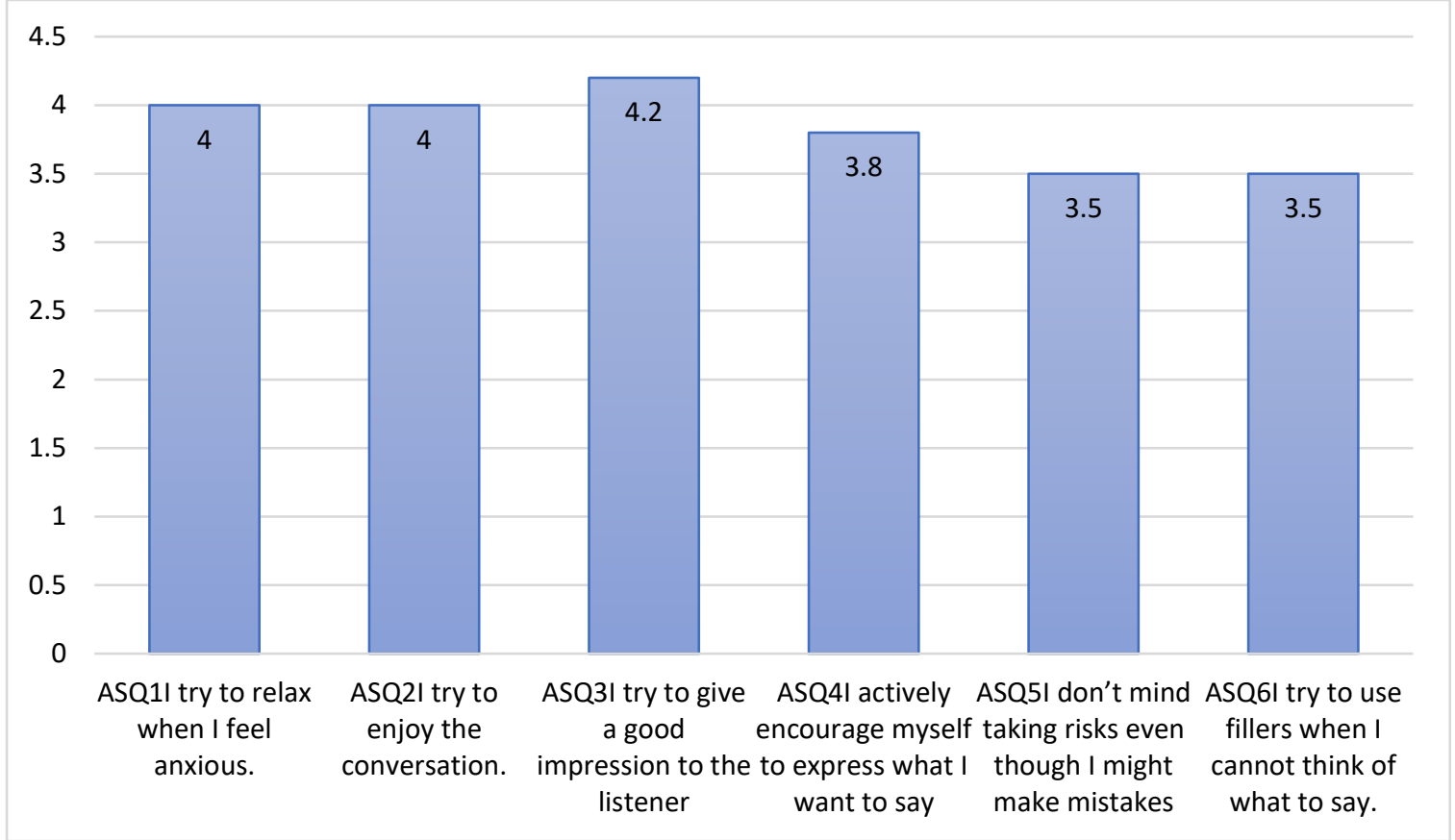

Figure 10- Mean for Social Affective Strategies

In finding (figure 10) out the Cognitive Factors, giving a good impression to the listener was found to be the most significant strategy used among the respondents with a mean value of 4.2. This is followed by trying to relax when anxious and trying to enjoy conversation, with a same mean value of 4 . As for the least used strategy, taking risks even though they might make mistakes and trying to use fillers when they cannot think of what to say were found to have the mean value of 3.5 for both. 


\section{(iii) Message Reduction, Orientation and Non-Verbal Strategies}

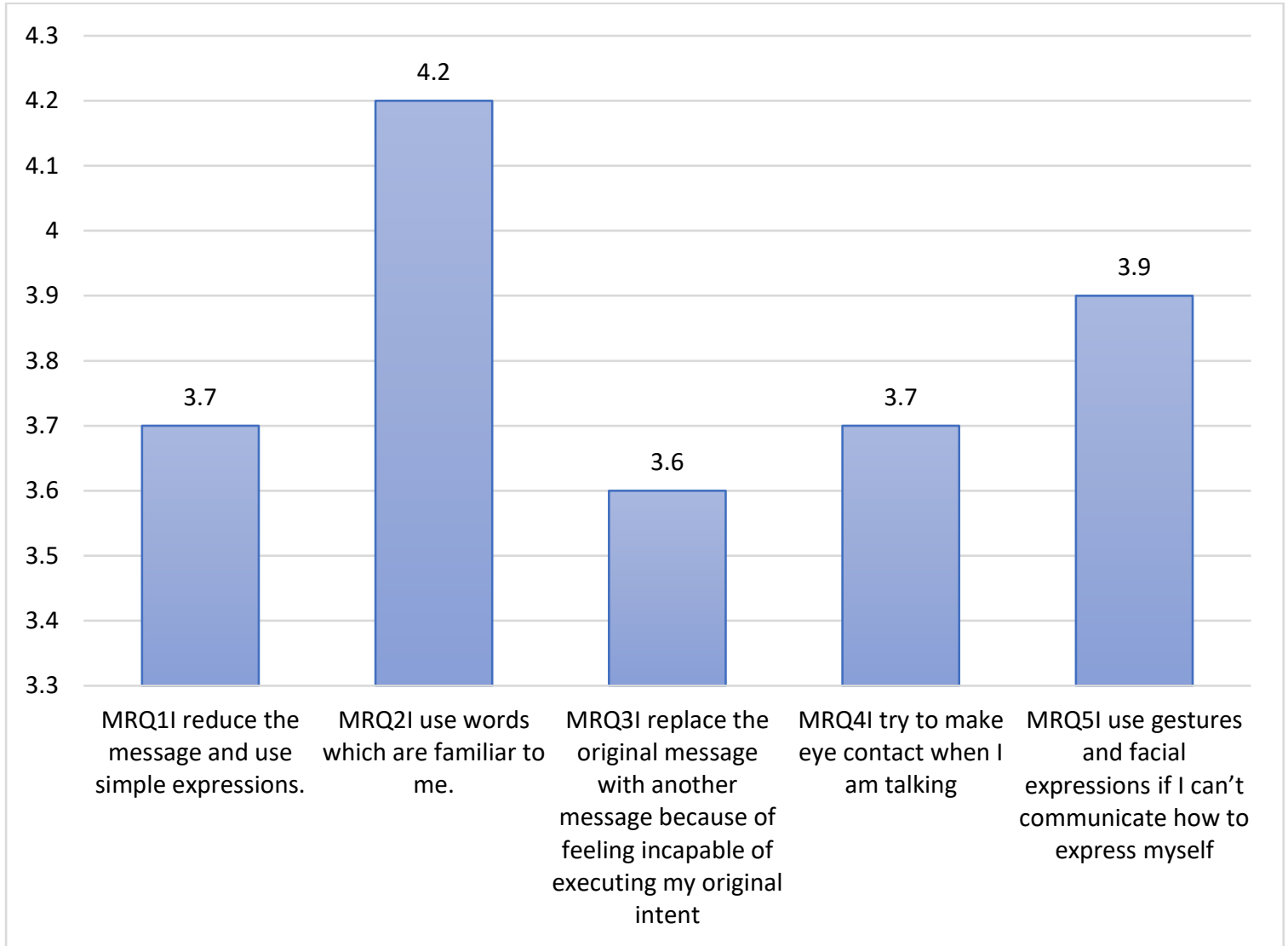

Figure 11- Mean for Message Reduction

Figure 11 illustrates the mean scores for five message reduction, orientation and non-verbal strategies items in the survey. With a mean value of 4.2, the respondents decided to utilise phrases that they are familiar with as the most preferred method opted. This is followed by using gestures and facial expressions when they were unable to express themselves with mean score recorded ( $M=3.9)$. Reduced the message and tried to make eye contact scored a mean value of 3.7 respectively. The least used strategy $(M=3.6)$ when the original message failed to carry out the original intent was to replace it with a new message 
Findings for Behaviour Factors

This section presents data to answer research question 3: How do behaviour factors influence the fear of public speaking? When learners fear public speaking, they may use (i) fluencyoriented strategies, and (ii) negotiation for meaning strategies to camouflage the fear.

\section{(i) Fluency Oriented Strategies}

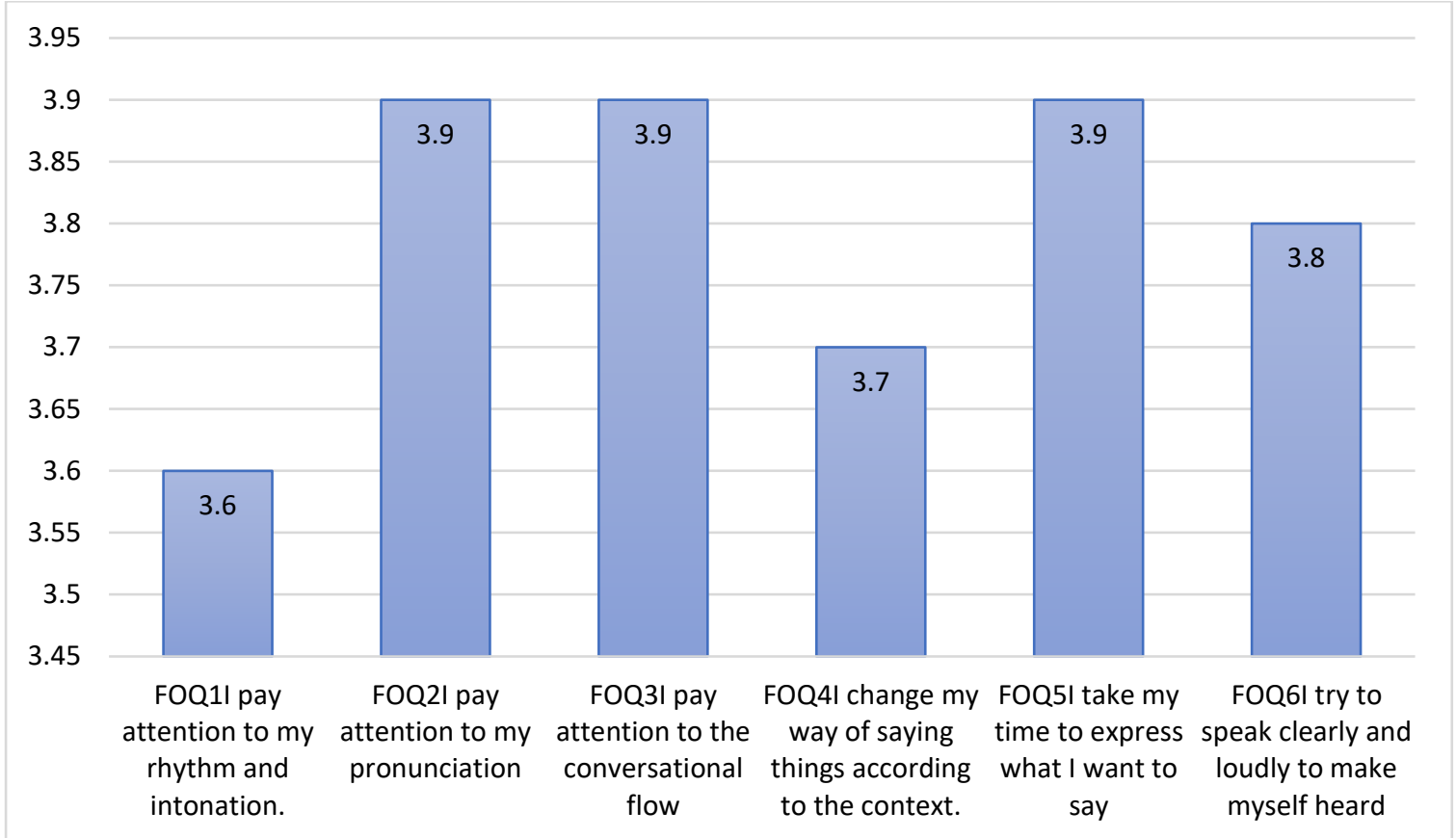

Figure 12- Mean for Fluency Oriented Strategies

Fluency-oriented strategies consist of six items in the questionnaire, as shown in Figure 12. It was evident that three most frequent strategies used by the respondents were paying attention to their pronunciation, conversational flow and taking their time to express what they want to say, with the mean score of 3.9 for each item. In contrast, the strategy of paying attention to rhythm and pronunciation was the least common strategy employed in oral communication, as indicated by the lowest mean value $(M=3.6)$. 


\section{(ii) Negotiation for Meaning Strategies}

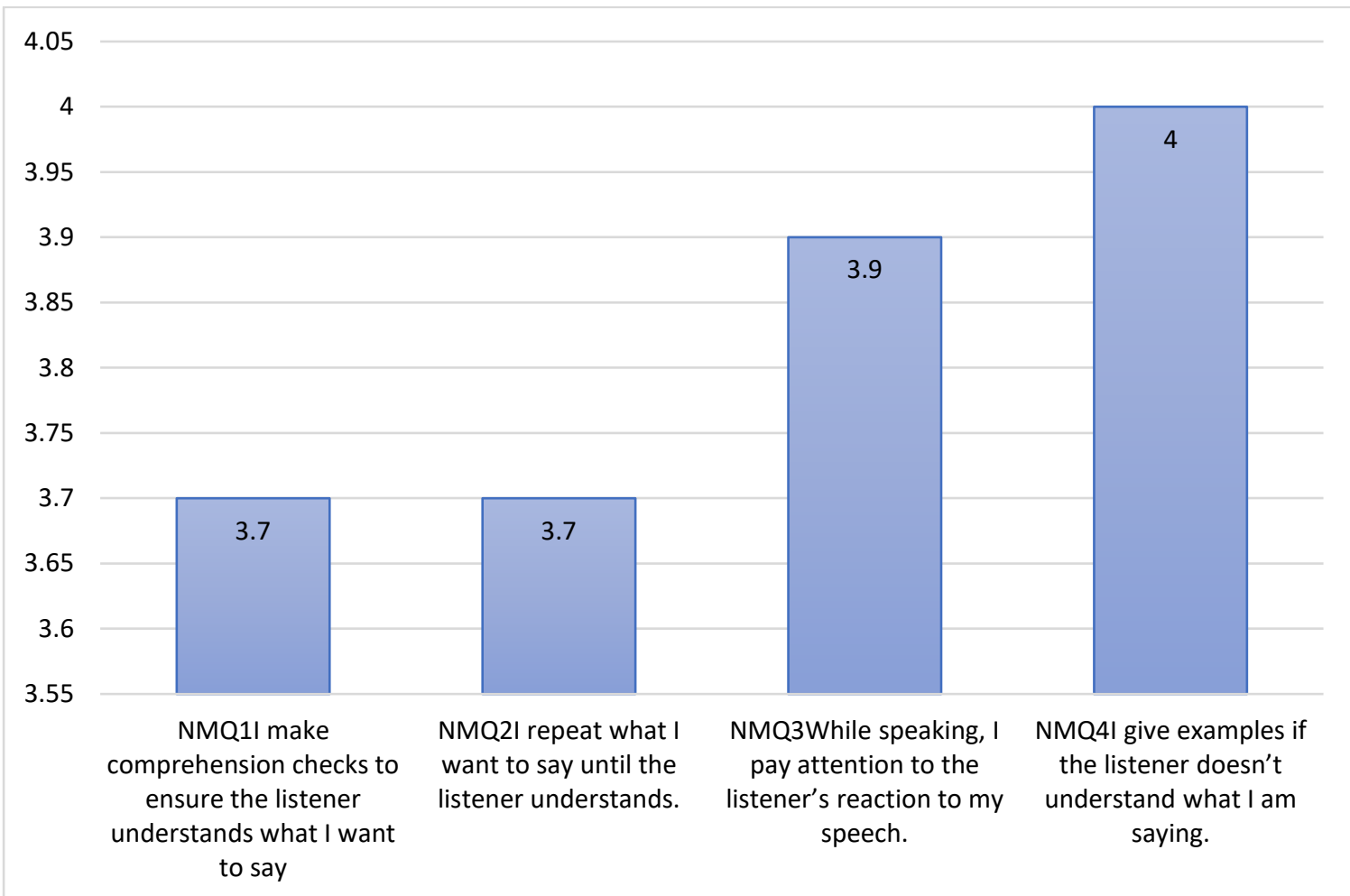

Figure 13- Negotiation for Meaning

As for negotiation for meaning strategies, it consists of 4 items, as shown in Figure 13. Giving examples if the listener doesn't understand was observed to be the most used strategy, with the mean value of 4 . The second most used strategy is paying attention to the listener's reaction, with the mean value of 3.9. As for the least used strategy, making comprehension checks to ensure the listener understands and repeating what to say until the listener understands are the least used strategies with a mean value of 3.7 for both.

\section{Conclusion}

\section{Summary of Findings and Discussion}

This study explores the causes of fear in public speaking among undergraduate students. In addition, it also discovers the student's anxiety in public speaking through the lens of Social Cognitive Theory. From the overall finding and discussion presented, the researchers found that learners have the fear of public speaking when they need to talk in front of a huge audience. In view of the findings, size and composition of the audience was the highest external factor that contributed to fear of public speaking $(M=3.9)$, while personal issues, time preferences, and worry about not being able to do better than the prior performance, recorded as the lowest external factors $(M=3.5)$. This is in accordance with the past study by Rajitha \& Alamelu (2020), which stated that peer factor or audiences was the main external factor of students' anxiety. Next, internal factors also evoke the occurrence of fear in public speaking. It is evident from the study that respondents' nervousness recorded the highest mean score $(M=4.2)$ and physical appearance was the least important factor for fear in public speaking $(M=3.5)$. This finding is consistent with Mulyani (2018), which found that students became nervous when they speak in front of their classmates. On the other hand, the findings claim another two causes of fear in public speaking such as cognitive factor and behavior factor. As stated in the result, the respondents believed that a good impression on the 
listener, correcting their own mistakes and using familiar words in speaking are the most popular strategies for them. These strategies allow them to feel at ease during speaking as well as boost their confidence level. Similarly, a study by Drury \& Ma (2002), emphasized the importance of self-correct to eliminate language barriers and communicate efficiently. Most of the respondents come to an agreement that fluency in speaking as well as virtuous interaction with listeners lead to an understanding in the communication process. According to Iswara et al (2012), they claimed that the successful content delivery made the utterances produced are fathomable easily by the listener. Hence, the implementation of these communicative strategies enables students to improve their speaking skills effectively.

Pedagogical Implications and Suggestions for Future Research

This paper discusses the fear of public speaking through the lens of social cognitive theory. Given the importance of public speaking in determining learners' language competency, more studies on their fear towards public speaking is vital. A larger sample and more comprehensive model can help in yielding better results. As reported by this study, learners feel nervous when they need to speak in a big number of audience. Teachers should create a more relaxing environment where students can improve their self-esteem and confidence when speaking in public. Teachers should also encourage students to utilize communication strategies to help them perform better in their public speaking. Since most teaching and learning has shifted to online platforms (Petronzi \& Petronzi, 2020), teachers can be more creative to assist students in performing better in public speaking. Teachers can utilize video blogging as it has been proven to bring positive effects towards learners' anxiety and fear towards public speaking (Madzlan et al., 2020). Since the educational landscape has changed towards more online teaching and learning, in depth study on learners' fear of public speaking in the context of online dimension should be conducted. This can give better insight and view to teachers and better lessons can be delivered to achieve desired outcomes.

\section{References}

Aida, Y. (1994). Examination of Horwitz, Horwitz, and Cope's Construct of Foreign Language Anxiety: The Case of Students of Japanese. The Modern Language Journal, 78(2), 155-168. https://doi.org/10.1111/j.1540-4781.1994.tb02026.x

Bandura, A. (1986). Social foundations of thought and action: A social cognitive theory. Prentice-Hall, Inc.

Bodie, G. D. (2010). A Racing Heart, Rattling Knees, and Ruminative Thoughts: Defining, Explaining, and Treating Public Speaking Anxiety. Communication Education, 59(1), 70-105. https://doi.org/10.1080/03634520903443849

Bartholomay, E. M., \& Houlihan, D. D. (2016). Public Speaking Anxiety Scale: Preliminary psychometric data and scale validation. Personality and Individual Differences, 94, 211215. https://doi.org/10.1016/j.paid.2016.01.026

Bataineh, R. F., Al-Bzour, W. K., \& Baniabdelrahman, A.A. (2017). On the teachability of communication strategies to Jordanian EFL beginners: Exploration and reflection. International Online Journal of Education and Teaching (IOJET), 4(3), 213-227. http://iojet.org/index.php/IOJET/article/view/154/167

Chollet, M., Wörtwein, T., Morency, L. P., Shapiro, A., \& Scherer, S. (2015). Exploring feedback strategies to improve public speaking. Proceedings of the 2015 ACM International Joint Conference on Pervasive and Ubiquitous Computing - UbiComp '15. Published. https://doi.org/10.1145/2750858.2806060 
Dansieh, S. A., Owusu, E., \& Seidu, G. A. (2021). Glossophobia: The Fear of Public Speaking in ESL Students in Ghana. Language Teaching, 1(1), p22. https://doi.org/10.30560/lt.v1n1p22

Dansieh, S. A. (2021). English Language Skill Needs of the Secretarial Student. International Journal of Literature, Language and Linguistics, 7(1): 276-289. Retrieved from https://www.researchgate.net/publication/350874198_English_Language_Skill_Needs _of_the_Secretarial_Student_English_Language_Skill_Needs_of_the_Secretarial_Stud ent

Dornyei, Z. (1995). On the Teachability of Communication Strategies. TESOL Quarterly, 29 (1), 55-85. https://doi.org/10.2307/3587805

Drury \& Ma. (2002). Do Language Barriers Result in Aviation Maintenance Errors? Proceedings of the Human Factors and Ergonomics Society Annual Meeting 47(1) DOI:10.1177/154193120304700110

Dwyer, K. K., \& Davidson, M. M. (2012). Is Public Speaking Really More Feared Than Death? Communication Research Reports, 29(2), 99 https://doi.org/10.1080/08824096.2012.667772

Endler, N. S. (1980). Person-situation interaction and anxiety. In I. L. Kutash (Ed.), Handbook on stress and anxiety. San Francisco:Jossey-Bass, pp.249-266.

Grieve, R., Woodley, J., Hunt, S. E., \& McKay, A. (2021): Student fears of oral presentations and public speaking in higher education: a qualitative survey, Journal of Further and Higher Education, DOI: 10.1080/0309877X.2021.1948509

Hancock, A. B., Stone, M. D., Brundage, S. B., \& Zeigler, M. T. (2010). Public Speaking Attitudes: Does Curriculum Make a Difference? Journal of Voice, 24(3), 302-307. https://doi.org/10.1016/j.jvoice.2008.09.007

Herbein, E., Golle, J., Tibus, M., Schiefer, J., Trautwein, U., \& Zettler, I. (2018). Fostering elementary school children's public speaking skills: A randomized controlled trial. Learning and Instruction, 55, 158-168.

https://doi.org/10.1016/j.learninstruc.2017.10.008

Kencanawati, D. (2014). Designing Communication Strategy in The English-Speaking Class At University. The 61 TEFLIN International Conference, UNS Solo, 509-512. https://core.ac.uk/download/pdf/43024982.pdf

LeFebvre, L., LeFebvre, L. E., \& Allen, M. (2018). Training the butterflies to fly in formation: cataloguing student fears about public speaking. Communication Education, 67(3), 348362. https://doi.org/10.1080/03634523.2018.1468915

Madzlan, N. A., Seng, G. H., \& Kesevan, H. V. (2020). Use of Video Blogs in Alleviating Public Speaking Anxiety among ESL Learners. Journal of Education and E-Learning Research, 7(1), 93-99. https://doi.org/10.20448/journal.509.2020.71.93.99

Mahmood, S. (2020). Instructional strategies for online teaching in COVID-19 pandemic. Hum. Behav. Emerging Tech. 3, 199-203. doi:10.1002/hbe2.218 Mitchell, R., \& Myles, F. (1998). Second Language Learning Theories. Arnold.

Sukirlan, M. (2014). Teaching Communication Strategies in an EFL Class of Tertiary Level. Theory and Practice in Language Studies, 4 (10), 2033-2041. DOI:10.4304/tpls.4.10.2033-2041

Mulyani, S. (2018). Investigating Factors Causing Students' Anxiety in Speaking English. International Journal in Applied Linguistics of Parahikma, 1(1), 1-19. https://www.researchgate.net/publication/325107390 
Nakatani, Y. (2006). Developing an Oral Communication Strategy Inventory. The Modern Language Journal, 90 (2), 151-168. https://doi.org/10.1111/j.1540-4781.2006.00390.x

Nakatani, Y. (2012). Exploring the Implementation of the CEFR in Asian Contexts: Focus on Communication Strategies. Procedia - Social and Behavioral Sciences, 46, 771-775. https://doi.org/10.1016/j.sbspro.2012.05.196

Anuar, N. A. K., Mokhtar, M. I., \& Hasan, H. (2018). Characterizations of Orang Asli (Indigenous) Students' Learning Strategies as Related to Self-Efficacy. Advanced Science Letters, 24(11), 8239-8242. https://doi.org/10.1166/asl.2018.12532

O'Malley, M. J., \& Chamot, A. U. (1990). Learning Strategies in Second Language Acquisition (Cambridge Applied Linguistics) (1st ed.). Cambridge University Press.

Panggabean, C. I. T., \& Wardhono, A. (2017). Communication strategies used by EFL students in their presentation. Indonesian EFL Journal: Journal of ELT, Linguistics, and Literature. Volume 3, Issue 2, Pages 39-54. P-ISSN: 2460-0938; E-ISSN: 2460-2604. Retrieved from http://ejournal.kopertais4.or.id/mataraman/index.php/efi/article/view/3228

Petronzi, R., \& Petronzi, D. (2020). The Online and Campus (OaC) model as a sustainable blended approach to teaching and learning in higher education: A response to COVID19. Journal of Pedagogical Research, 4(4), 498-507. https://doi.org/10.33902/JPR.2020064475

Putri, L. A. (2013). Communication Strategies in English as a Second Language (ESL) Context. Advances in Language and Literary Studies, 4 (1), 129-133. https://files.eric.ed.gov/fulltext/EJ1129727.pdf

Rajitha \& Alamelu. (2020). A Study of Factors Affecting and Causing Speaking Anxiety (January 2020). Procedia Computer Science, 172:1053-1058 DOI:10.1016/j.procs.2020.05.154

Rastegar, M., \& Gohari, S. S. M. (2016). Communication Strategies, Attitude, and Oral Output of EFL Learners: A Study of Relations. Open Journal of Modern Linguistics, 6, 401-419. http://dx.doi.org/10.4236/ojml.2016.65036

Rivers, W. M. (1981). Teaching Foreign Language Skills: Second Edition (Second ed.). University of Chicago Press.

Singh, C. (2021). Why flipped classes often flop. Inside Higher. Available at: https://www.insidehighered.com/advice/2021/01/20/lessons-learned-duringpandemic-about-how-teach-flipped-classes-most-effectively

Tan, K. H., Nor, M. N. F., \& Jaradat, M. N. (2012), Communication Strategies among EFL Students - An Examination of Frequency of Use and Types of Strategies Used. GEMA Online Journal of Language Studies. Volume 12(3), Special Edition, September 2012. ISSN: 1675-8021. Retrieved from https://core.ac.uk/reader/11494415

Tarone, E. (1981). Some Thoughts on the Notions of Communication Strategy. TESOL Quarterly, 15 (3), 285-295. http://dx.doi.org/10.2307/3586754

Tilfarlioglu, F. Y., \& Ciftci, F. S. (2011). Supporting Self-efficacy and Learner Autonomy in Relation to Academic Success in EFL Classrooms (A Case Study). Theory and Practice in Language Studies, 1(10). https://doi.org/10.4304/tpls.1.10.1284-1294

Toubot, A., Seng, G. H., \& Abdullah, A. B. A. (2017). Overview of speaking anxiety among EFL students. Journal of the Social Science, 12(11), 1938-1947. Available at: https://medwelljournals.com/abstract/?doi=sscience.2017.1938.1947 https://doi.org/ 10.36478/sscience.2017.1938.1947

Wang, C., \& Pape, S. J. (2005). Self-efficacy beliefs and self-regulated learning strategies in learning English as a second language: Four case studies. The CATESOL Journal, 17(1), 
76-90. Available at: http://www.catesoljournal.org/wpcontent/uploads/2014/07/CJ17_wang.pdf

Wang, J., Yang, H., Shao, R., Abdullah, S., \& Sundar, S. S. (2020). Alexa as Coach: Leveraging Smart Speakers to Build Social Agents that Reduce Public Speaking Anxiety. Proceedings of the $2020 \mathrm{CHI}$ Conference on Human Factors in Computing Systems. Published. https://doi.org/10.1145/3313831.3376561

Wrench, J. S., Goding, A., Johnson, D. I., \& Attias, B. A. (2012). Public speaking: Practice and ethics. http://2012books.lardbucket.org/books/publicspeaking-practice-and-ethics/

Yaman, S., \& Irgin, P. (2013). The Validity and Reliability Studies of The Oral Communication Strategy Inventory. Journal of Education, 28 (1), 417-427.

https://www.researchgate.net/publication/272094439_The_validity_and_reliability_s tudies_of_the_oral_communication_strategy_inventory

Yaman, Ş., \& Kavasoğlu, M. (2013). The adaptation study of oral communication strategy inventory into Turkish.

Zhou, J., \& Huang, L. S. (2018). An Exploration of Strategies Used by Chinese Graduate Students in Electrical Engineering and Education: Integrating Questionnaire, Task Performance and Post-Task Recall Data. Asian Pacific Journal of Second and Foreign Language Education, 3 (15), 1-22. DOI: https://doi.org/10.1186/s40862-018-0054-2

Zulkurnain, N., \& Kaur, S. (2014). Oral English communication difficulties and coping strategies of Diploma of Hotel Management Students at UiTM. 3L; Language, Linguistics and Literature, The Southeast Asian Journal of English Language Studies., 20 (3). pp. 93112. ISSN 0128-5157. Retrieved from http://journalarticle.ukm.my/7741/1/607818848- 1-PB.pdf 